Volume 2 Issue 2, September 2017: pp. 119-128. Copyright @ LamLaj. Faculty of Law, Lambung Mangkurat University, Banjarmasin, South Kalimantan, Indonesia. ISSN: 2502-3136 | e-ISSN: 2502-3128. Open Access at: http://lamlaj.ulm.ac.id/web/

\title{
PEMBATASAN JANGKA WAKTU PENUNDAAN KEWAJIBAN PEMBAYARAN UTANG TERHADAP DEBITOR DALAM KEPAILITAN
}

\author{
Novitasari \\ Fakultas Hukum Universitas Lambung Mangkurat. \\ Brigjend H. Hasan Basri Komplek Banjarmasin, 70123, Indonesia \\ Telp:05113307877Fax:+E-mail : Novitaaeffendi@gmail.com
}

Submitted: 14/09/2017; Reviewed:21/09/2017; Accepted: 25/09/2017

\begin{abstract}
The aims of the research is to analyze reasons for short term restriction on the Postponement of Debt Payment Obligation (PDPO), the existence of time limit provisions resulting the failure of the debtors'debt efforts with creditors, and the PKPU's term limits on legal protection for the interests of debtors to prevent bankruptcy. This research is a normative juridical research. Data used in this research were secondary data obtained from official documents, books related to the object of research, research results in the form of reports, bachelor thesis, master thesis, dissertation and regulations. This research was also supported with primary data by conducting an interview with Advocates as resource persons to support the research. Data were analyzed qualitatively. The results of the research indicated that: (1) the term restriction given by Law no. 37 of 2004 concerning Bankruptcy and Postponement of Debt Payment Obligation has an objective of making debtors able to offer amicable resolution to creditors related to debt payments so that debtors can continue their business. (2) The term is not a determinant of the failure of amicable resolution effort in the Postponement of Debt Payment Obligation, but affect the process of achieving the Postponement of Debt Payment Obligation, (3) Law No. 37 of 2004 concerning Bankruptcy and Postponement of Debt Payment Obligation provides security guarantee such as giving the debtors an opportunity to reorganize business or company management or to restructure their debts within the period of Postponement of Debt Payment Obligation, and the debtor does not lose their rights to take care of the company and assets, so that the debtors still have the authority to manage the company. It can be concluded from the research that (1) Law no. 37 of 2004 concerning Bankruptcy and Postponement of Debt Payment Obligation provides a short term for the debtors so that the debtors are really able to make amicable resolution to the creditor in relation to the payment of debts. (2). The term is not a determinant of the failure of amicable resolution effort in the Postponement of Debt Payment Obligation, but affect the process of achieving the Postponement
\end{abstract}


of Debt Payment Obligation. (3). Law no. 37 of 2004 concerning Bankruptcy and Postponement of Debt Payment Obligation has provided a guarantee of legal protection in the form of certainty to the debtor to prevent bankruptcy.

Keywords: Term; Postponement of Debt Payment Obligation; Debtors.

Abstrak:Penelitian ini bertujuan untuk (1) mengidentifikasi dan memeriksa pembatasan jangka pendek atas Penundaan Utang Pembayaran Utang (PDPO) dalam Undang-undang. 37 tahun 2004 tentang Pailit dan Penundaan Kewajiban Pembayaran Utang, (2) Mengidentifikasi dan memeriksa Ketentuan Kewajiban Pembayaran Utang (PDPO) dalam UU No. 37 tahun 2004 tentang Kebangkrutan dan Penundaan Kewajiban Pembayaran Utang yang membuat upaya debitur untuk menyelesaikan masalah dengan baik dengan kreditur gagal; (3) Mengidentifikasi dan memeriksa peraturan dalam UU No. 37 tahun 2004 tentang Kebangkrutan dan Penundaan Kewajiban Pembayaran Utang sehubungan dengan perlindungan hukum bagi debitur untuk mencegah kebangkrutan. Penelitian ini merupakan penelitian yuridis normatif. Data yang digunakan dalam penelitian ini adalah data sekunder yang diperoleh dari dokumen resmi, buku yang berhubungan dengan objek penelitian, hasil penelitian berupa laporan, tesis sarjana, tesis master, disertasi dan peraturan. Penelitian ini didukung oleh data primer dengan melakukan wawancara dengan Advokat sebagai narasumber untuk mendukung penelitian. Data dianalisis secara kualitatif. Hasil penelitian menunjukkan bahwa: (1) istilah pembatasan yang diberikan oleh UU No. 37 tahun 2004 tentang Bangkrut dan Penundaan Kewajiban Pembayaran Utang bertujuan membuat debitur dapat memberikan penyelesaian damai kepada kreditor terkait dengan pembayaran hutang sehingga debitur dapat melanjutkan usaha mereka. (2) Istilah ini bukan merupakan penentu kegagalan upaya penyelesaian damai dalam Penundaan Utang Pembayaran Utang, namun mempengaruhi proses pencapaian Penundaan Kewajiban Pembayaran Utang, (3) UU No. 37 tahun 2004 tentang Kebangkrutan dan Penundaan Utang Utang menetapkan bahwa debitur 'mengurus perusahaan dan aset, sehingga debitur masih memiliki kewenangan untuk mengelola perusahaan. Dapat disimpulkan dari penelitian bahwa (1) UU No. 37 tahun 2004 tentang Pailit dan Penundaan Kewajiban Pembayaran Utang memberikan jangka pendek agar debitur dapat melakukan penyelesaian secara damai kepada kreditur sehubungan dengan pembayaran hutang. (2). Istilah ini bukan merupakan penentu kegagalan upaya penyelesaian damai dalam Penundaan Utang Pembayaran Utang, namun mempengaruhi proses pencapaian Penundaan Utang Utang. (3). UU No. 37 tahun 2004 tentang Pailit dan Penundaan Kewajiban Pembayaran Utang telah memberikan jaminan perlindungan hukum dalam bentuk kepastian kepada debitur untuk mencegah kebangkrutan

Kata Kunci: Debitor; Jangka Waktu; Penundaan Kewajiban Pembayaran Utang 


\section{PENDAHULUAN}

Kegiatan perusahaan pada umumnya dijalankan dengan tujuan untuk memperoleh keuntungan yang maksimal sesuai dengan pertumbuhan perusahaan tersebut dalam jangka panjang. Kehadiran perusahaan diharapkan dapat membuka lapangan pekerjaan dan menyejahterakan tenaga kerja, serta menyediakan barang dan atau jasa yng diperlukan oleh masyarakat. Selain itu kehadiran perusahaaan juga diharapkan dapat memberikan kontribusi pada pembangunan nasional baik itu melalui pembayaran pajak maupun tanggung jawab sosial lainnya. ${ }^{1}$

Kehadiran perusahaan tidak semuanya memperoleh keuntungan dan memenuhi harapan seperti yang direncanakan. Banyak perusahaan yang mengalami kerugian yang mengarah pada likuiditas, sehingga tidak mampu melanjutkan usaha dan melakukan pemutusan hubungan kerja. Hal ini terjadi, antara lain karena dalam menjalankan kegiatan usaha pengurus perusahaan tidak memiliki kemampuan membuat kebiajakan-kebijakan dalam meperoleh, mengelola dan menggunakan sumber-sumber ekonomi yang dimiliki dengan cepat. Selain itu, perusahaan tersebut tidak beroperasi sesuai dengan ketentuan yang berlaku dan tidak menerapkan etika bisnis dengan baik. ${ }^{2}$

Undang-Undang Nomor 37 Tahun 2004 tentang Kepailitan dan Penundaan Kewajiban Pembayaran Utang (Lembaran Negara Republik Indonesia Tahun 2004 Nomor 131, Tambahan Lembaran Negara Republik Indo-

1 R.Anton Suyatno. 2012. Pemanfaatan Penundaan Kewajiban Pembayaran Utang Sebagai Upaya Mencegah Kepailitan. Jakarta: Kencana Prenada Media Group, hlm. 1.

2 Haidar Bagir. 1995. Era Baru Manajemen Etis. Jakarta: Mizan. hlm. 5. nesia Nomor 4433; untuk selanjutnya disebut UU No. 37/2004) memberikan dua cara agar debitor dapat terhindar dari ancaman harta kekayaannya dilikuidasi, ketika debitor telah atau akan berada dalam keadaan insolven, terhadap usahanya, yaitu:

1. Mengadakan perdamaian antara debitor dengan para kreditornya setelah debitor dinyatakan pailit oleh pengadilan. Perdamaian tersebut dapat mengakhiri kepailitan debitor hanya apabila dibicarakan bersama dan melibatkan semua kreditor. Apabila perdamaian hanya diajukan dan dirundingkan dengan hanya satu atau beberapa kreditor, tidak dapat mengakhiri kepailitan debitor;

2. Mengajukan Penundaan Kewajiban Pembayaran Utang (PKPU) atau surseance van betaling atau suspension of payment. Ketentuan PKPU diatur dalam Bab III, mulai Pasal 222 sampai dengan Pasal 294 UU No. 37/2004. Dalam Pasal 222 ayat (2) UU No. 37/2004 ditegaskan bahwa tujuan dari pengajuan PKPU adalah untuk mengajukan rencana perdamaian yang meliputi tawaran pembayaran, sebagian atau seluruh utang kepada kreditor. Menurut Penjelasan Pasal 222 ayat (2) tersebut, bahwa yang dimaksud "kreditor" adalah baik kreditor kongkuren maupun kreditor yang didahulukan. ${ }^{3}$

PKPU adalah suatu keadaan saat debitor tidak dapat atau memperkirakan, bahwa ia tidak dapat melanjutkan membayar utangutangnya yang sudah jatuh tempo dan dapat ditagih, dapat memohon PKPU kepada

3 Sutan Remy Sjahdeini .2008. Hukum Kepailitan Memahami Undang-undang No.37 Tahun 2004 tentang Kepailitan. Jakarta: Grafiti, hlm. 327. 
kreditor kongkuren. ${ }^{4}$

Ada dua jenis PKPU yang dikenal dalam UU No. 37/2004, yaitu PKPU sementara dan PKPU tetap. Kedua jenis PKPU tersebut merupakan sebuah tahapan dan memiliki batas waktu. PKPU sementara diatur dalam Pasal 225 ayat (4) UU No. 37/2004, yang menyebutkan:

Segera setelah putusan penundaan kewajiban pembayaran utang sementara diucapkan, Pengadilan melalui pengurus wajib memanggil Debitor dan Kreditor yang dikenal dengan surat tercatat atau melalui kurir, untuk menghadap dalam sidang yang diselenggarakan paling lama pada hari ke-45 (empat puluh lima) terhitung sejak putusan penundaan kewajiban pembayaran utang sementara diucapkan.

Sementara itu, PKPU tetap diatur dalam Pasal 228 ayat (6) UU No. 37/2004 yang menyebutkan:

Apabila penundaan kewajiban pembayaran utang tetap sebagaimana dimaksud pada ayat (4) disetujui, penundaan tersebut berikut perpanjangannya tidak boleh melebihi 270 (dua ratus tujuh puluh) hari setelah putusan penundaan kewajiban pembayaran utang sementara diucapkan.

Mekanisme PKPU dalam praktik merupakan solusi yang baik, tidak hanya bagi debitor untuk bisa terhindar dari keadaan pailit, namun juga secara sosial dan ekonomi menjadi solusi bagi karyawan dan stakeholder lainnya. Dengan berhasilnya dilakukan restrukturisasi utang bagi debitor melalui mekanisme PKPU, maka usaha debitor akan masih tetap beroperasi, sehingga sekurang-

4 Richard Burton Simatupang. 2007. Aspek Hukum Dalam Bisnis. Jakarta: Rineka Cipta, hlm. 175. kurangnya karyawan masih tetap bisa bekerja dan tidak kehilangan mata pencahariannya.

Faktanya dalam beberapa pemberitaan media massa ada beberapa kasus para debitor yang permohonan melakukan PKPU justru tidak diterima atau ditolak oleh Pengadilan Niaga akibat tidak disepakatinya upaya perdamaian dari debitor dan para kreditornya. Misalkan dalam kasus PT Effendi Textindo, Majelis Hakim Pengadilan Niaga Jakarta Pusat akhirnya memutuskan pailit. Vonis pailit tersebut dijatuhkan setelah Effendi Textindo gagal mengajukan proposal perdamaian kepada para kreditornya. Sementara waktu maksimal pembahasan PKPU tersebut, yakni 270 hari telah berakhir. Ketua Majelis Hakim Bambang Kustopo mengatakan, waktu perpanjangan PKPU yang diberikan kepada Effendi Textindo telah mencapai batas waktu 270 hari. Kendati waktu yang diberikan sudah maksimal, namun tidak terjadi perdamaian antara debitor dan kreditor. Karena itu, berdasarkan UU PKPU dan Kepailitan, maka Effendi Textindo harus dinyatakan pailit. ${ }^{5}$

Dalam kasus lain PT Jaba Garmindo dan Djoni Gunawan akhirnya juga dinyatakan pailit oleh Pengadilan Niaga pada Pengadilan Negeri Jakarta Pusat. Pailit terhadap perusahaan tekstil dan penjamin pribadi itu diputuskan oleh majelis hakim setelah proposal rencana perdamaian yang diajukan oleh Jaba Garmindo ditolak oleh para kreditor. PT Jaba Garmindo dan Djoni Gunawan dalam kondisi pailit dengan segala akibat hukumnya, kata Ketua Majelis Hakim Jamaluddin Samosir dalam amar putusan yang dibacakan. Menurut Jamal, berdasarkan hasil pemungutan suara proposal perdamaian, hanya dua kreditor

5 http://nasional.kontan.co.id/news/pengadilanputuskan-effendi-textindo-pailit. Diakses 20 Januari 2017 
separatis dari Jaba Garmindo dengan tagihan Rp173 miliar atau setara 12,51\% suara yang menerima proposal perdamaian. Sisanya, sebanyak 10 kreditor dengan total tagihan Rp1,2 triliun atau 87,49\% suara dan seluruh kreditor kongkuren menyatakan menolak rencana perdamaian dari Jaba Garmindo. Seluruh kreditor kongkuren dari Djoni juga menolak proposal perdamaian. Kreditor separatis yang menyetujui sebanyak 16,01\% dari dua kreditor, dan yang menolak sebanyak $83,99 \%$ dari enam kreditor. ${ }^{6}$

Pengadilan Niaga Jakarta Pusat juga memutuskan memailitkan Purdi E. Chandra. Vonis ini keluar lantaran proses PKPU atas pendiri bimbingan belajar (bimbel) Primagama itu gagal tercapai. Dalam sidang yang dipimpin Ketua Majelis Hakim Lidya Sasando, Rabu (12/6) menyatakan termohon PKPU Purdi E. Chandra dalam keadaan pailit dengan segala hukumnya. Sampai batas akhir masa PKPU, Majelis Hakim tidak mendapatkan laporan adanya mediasi dengan pihak penggugat, BNI Syariah sehingga tidak tercapai kesepakatan perdamaian antara kreditor dengan Purdi selaku debitor. ${ }^{7}$

Dari beberapa contoh kasus diatas dapat terlihat bahwa Debitor yang mengajukan proses PKPU justru menjadi pailit setelah mengajukan PKPU, karena keadaan tidak mampu membuat kesepakatan mengenai isi Rencana Perdamaian dengan para kreditornya dalam proses PKPU sesuai jangka waktu yang ditentukan dalam Pasal 225 ayat (4) dan Pasal 228 ayat (5) UU No. 37/2004, sehing-

6 http://www.hukumonline.com/berita/baca// rencana-perdamaian-ditolak-jaba-garmindopailit. Diakses 22 Januari 2017

7 http://nasional.kontan.co.id/news/pengadilanpailitkan-pendiri-primagama. Diakses 22 Januari 2017 ga perlu diteliti urgensi pembatasan jangka waktu PKPU terhadap debitor dalam hukum kepailitan, implikasi pembatasan jangka waktu PKPU bagi rencana perdamaian debitor dengan para para kreditornya, dan perlindungan hukum bagi kepentingan debitor untuk mencegah kepailitan dalam pembatasan jangka waktu PKPU.

\section{METODE}

Jenis penelitian hukum ini merupakan penelitian yuridis normatif, karena menggunakan data sekunder atau studi kepustakaan. Penelitian normatif adalah penelitian hukum yang meletakan hukum sebagai sebuah bangunan sistem norma. Sistem norma yang dimaksudkan adalah mengenai asas-asas, norma, kaidah dari peraturang perundang-undangan, putusan pengadilan, perjanjian serta doktrin (ajaran). ${ }^{8}$ Penelitian ini juga didukung dengan melakukan wawancara kepada hakim justiabel dan advokad sebagai narasumber untuk menunjang penelitian ini.

Seluruh data yang diperoleh dalam penelitian ini, dianalisis secara kualitatif dan lengkap terhadap keseluruhan data yang diperoleh dalam penelitian yuridis normatif. Analisis kualitatif adalah menguraikan bahan hukum atau data secara bermutu dalam bentuk kalimat yang teratur, runtun, logis dan tidak tumpang tindih dan efektif, sehingga memudahkan interpretasi data dan pemahaman hasil analisis tersebut. ${ }^{9}$

8 Mukti Fajar Nur Dewata dan Yulianto Achmad. 2010. Dualisme Penelitian Normatif dan Empiris. Yogyakarta: Pustaka Pelajar, hlm. 34.

9 Purba, Jamslin. 2013. Perlindungan Hukum Terhadap Kreditor Kecil Melalui Penundaan Kewajiban Pembayaran Utang Berdasarkan Undang-Undang No. 37 Tahun 2004 tentang Kepailitan dan Penundaan Kewajiban Pembayaran Utang (PKPU) Sebagai Sarana Restrukturisasi 
Dalam penelitian hukum ini data yang diperoleh akan dianalisis secara deskriptif kualitatif. Data yang diperoleh, baik dari bahan hukum primer maupun sekunder akan diedit (editing), kemudian diuraikan dalam bentuk uraian yang logis dan sistematis. Data yang dianalisis tersebut menggunakan metode deduktif. Metode deduktif yang dimaksud adalah suatu metode yang berhubungan permasalahan yang diteliti dari peraturan-peraturan umum menuju penulisan yang bersifat umum.

\section{ANALISIS DAN PEMBAHASAN}

Urgensi Adanya Batasan Waktu yang Singkat dalam Penundaan Kewajiban Pembayaran Utang

PKPU adalah suatu keringanan yang diberikan kepada suatu debitor untuk menunda pembayaran utangnya, si debitor mempunyai harapan dalam waktu yang relatif tidak lama akan memperoleh penghasilan yang akan cukup melunasi semua utang-utangnya. ${ }^{10}$

Dalam Pasal 222 ayat (2) UU No. 37/2004 ditegaskan bahwa PKPU adalah prosedur hukum (atau upaya hukum) yang memberikan hak kepada setiap debitor yang tidak dapat atau memperkirakan bahwa ia tidak akan dapat melanjutkan membayar utang-utangnya yang sudah jatuh waktu dan dapat ditagih, dapat memohon penundaan kewajiban pembayaran utang, dengan maksud pada umumnya untuk mengajukan rencana perdamaian yang meliputi tawaran pembayaran seluruh

Utang Debitor. Yogyakarta: Fakultas Hukum UGM, hlm. 53.

10 Robinton Sulaiman dan Joko Prabowo. 2000. Lebih Jauh Tentang Kepailitan (Tinjauan Yuridis Tanggung Jawab Komisaris, Direksi dan Pemegang Saham Terhadap Perusahaan Pailit). Karawaci: Fakultas Hukum Universitas Pelita Harapan, hlm. 32. atau sebagian utang kepada kreditor kongkuren.

PKPU dapat diajukan secara sukarela oleh debitor yang telah memperkirakan bahwa ia tidak akan dapat membayar utang-utangnya. Failissementsverordening (FV) menentukan lamanya waktu PKPU adalah selama satu setengah tahun. PKPU tersebut dapat diperpanjang untuk jangka waktu yang sama, yaitu satu setengah tahun. Jangka waktu tersebut mulai berlaku sejak hari pemberian PKPU sementara. ${ }^{11}$ Pemberian PKPU sementara ini harus disegera diberikan oleh Pengadilan Negeri sebelum PKPU tetap diberikan. Namun FV tidak menentukan berapa lama batas "segera" itu. Total jangka waktu PKPU tersebut dapat lebih dari tiga tahun. ${ }^{12}$

Sejak berlakunya Undang-Undang Nomor 4 Tahun 1998 tentang Penetapan Peraturan Pemerintah Pengganti Undang-Undang Nomor 1 Tahun 1998 tentang Perubahan Atas Undang-Undang tentang Kepailitan Menjadi Undang-Undang (Lembaran Negara Republik Indonesia Tahun 1998 Nomor 135, Tambahan Lembaran Negara Republik Indonesia Nomor 3778; untuk selanjutnya disebut UU No. 4/1998), jangka waktu tersebut semakin dipersingkat sebagaimana diatur dalam 217 yang bersangkutan, yaitu tidak boleh lebih dari 270 hari termasuk perpanjangannya, terhitung sejak putusan penundaan kewajiban pembayaran utang sementara ditetapkan. Penentuan berapa lama batas "segera" dalam pemberian PKPU juga tidak diatur dalam UU No. 4/1998. Maksud adanya perubahan ini sebagaimana dijelaskan dalam UU No. 4/1998 adalah agar terdapat kepastian men-

11 Siti Anisah. 2008. Perlindungan Kepentingan Kreditor dan Debitor Dalam Hukum Kepailitan Di Indonesia. Yogyakarta: Total Media, hlm. 160.

12 Ibid, 
genai jangka waktu PKPU yang di dalamnya terdapat rencana perdamaian perlu dibicarakan dan diputuskan oleh kreditor. Adapun alasan yang melatar belakangi lahirnya Peraturan Pemerintah Pengganti Undang-Undang Nomor 1 Tahun 1998 tentang Kepailitan yaitu untuk menciptakan kepastian hukum bagi kepentingan dunia usaha untuk mengatasi persoalan akibat krisis moneter, sehingga diperlukan penyelesaian piutang secara adil, cepat dan terbuka.

Dalam pembaharuan hukum kepailitan melalui UU No. 37/2004 diatur ketentuan mengenai jangka waktu pemberian PKPU sementara maupun PKPU tetap sebagai berikut:

\section{PKPU sementara}

Sebelum Pengadilan Niaga memutuskan untuk mengadakan pemberian PKPU tetap, baik debitor maupun kreditor dapat mengajukan untuk diberikan putusan PKPU sementara sebagaimana diatur dalam Pasal 225 ayat (2), ayat (3) dan ayat (4) UU No. 37/2004 yang bunyinya sebagai berikut:

(1) Dalam hal permohonan diajukan oleh Debitor, Pengadilan dalam waktu paling lambat 3 (tiga) hari sejak tanggal didaftarkannya surat permohonan sebagaimana dimaksud dalam Pasal 224 ayat (1) harus mengabulkan penundaan kewajiban pembayaran utang sementara dan harus menunjuk seorang Hakim Pengawas dari hakim pengadilan serta mengangkat 1 (satu) atau lebih pengurus yang bersama dengan Debitor mengurus harta Debitor.

(2) Dalam hal permohonan diajukan oleh Kreditor, Pengadilan dalam waktu paling lambat 20 (dua puluh) hari sejak tanggal didaftarkannya surat permohonan, harus mengabulkan permohonan penundaan kewajiban pembayaran utang sementara dan harus menunjuk Hakim Pengawas dari hakim pengadilan serta mengangkat 1 (satu) atau lebih pengurus yang bersama dengan Debitor mengurus harta Debitor.

(3) Segera setelah putusan penundaan kewajiban pembayaran utang sementara diucapkan, Pengadilan melalui pengurus wajib memanggil Debitor dan Kreditor yang dikenal dengan surat tercatat atau melalui kurir, untuk menghadap dalam sidang yang diselenggarakan paling lama pada hari ke-45 (empat puluh lima) terhitung sejak putusan penundaan kewajiban pembayaran utang sementara diucapkan.

Setelah Pengadilan Niaga memberikan PKPU sementara, agar segera terjadi keadaan (stay atau standsstill).

\section{PKPU tetap jangka waktu}

Untuk menetapkan apakah kepada debitor akan diberikan PKPU secara tetap harus dilakukan dalam suatu persidangan yang merupakan rapat permusyawaratan hakim (rechbank in raddkamer) paling lambat pada hari ke 45 terhitung setelah putusan PKPU sementara ditetapkan. Dalam hal ini PKPU secara tetap akan ditetapkan oleh Pengadilan Niaga, jika hal itu mendapat persetujuan lebih dari $1 / 2$ kreditor kongkuren yang hadir pada sidang dan mewakili paling sedikit $2 / 3$ bagian dari seluruh tagihan kreditor kongkuren yang hadir atau diwakili dalam sidang tersebut. Jadi, dengan adanya ketentuan tersebut, ketidakhadiran kreditor 
kongkuren atau diwakili dalam sidang tidak mempengaruhi kourum. Selain itu, tidak hadirnya para kreditor kongkuren tidak dapat ditafsirkan bahwa mereka tidak menyetujui pemberian PKPU sebagaimana ditegaskan dalam Pasal 229 ayat (1) UU No. 37/2004. Jangka waktu yang ditetapkan tidak melebihi 270 hari terhitung sejak putusan PKPU sementara ditetapkan.

Sebagai perbandingan, dalam kerangka reorganisasi, di Amerika Serikat debitor dapat menunda pembayaran tagihan pajak dalam waktu lebih dari 6 tahun. Demikian pula debitor dapat membayar kepada kreditor lebih dari waktu yang telah disepakati sebelumnya, selama pembayarannya sama dengan nilai tagihan pada saat pinjaman diberikan oleh kreditor. ${ }^{13}$

Sedangkan di Belanda, apabila penundaan pembayaran utang tetap disahkan, maka District Court ( Rechtsbank) menentukan lamanya penundaan pembayaran maksimal selama 18 bulan. Apabila masa itu habis, maka penundaan pembayaran utang dapat diperbaharui maksimal 18 bulan. Setelah tiap waktu berakhir, jangka waktu itu dapat diperpanjang kembali. ${ }^{14}$

Undang-Undang Kepailitan Jerman menentukan di dalam rencana perdamaian harus ditetapkan dengan tepat lamanya waktu penundaan kewajiban pembayaran utang, namun undang-undang tersebut tidak memberikan batasan waktu lamanya penundaan kewajiban pembayaran utang. ${ }^{15}$

Pemberian jangka waktu PKPU selama 3 tahun sebagaimana diatur dalam FV dapat

13 Siti Anisah. Op.Cit, hlm. 162.

14 Ibid, hlm. 162.

15 Ibid, hlm. 163. pula ditemukan di Belgia. Berdasarkan Act of Judicial Composition 17 Juli 1997 di Belgia, Judicial Composition diberikan kepada debitor, jika debitor memenuhi beberapa persyaratan. Pertama, debitor untuk sementara waktu tidak mampu membayar utang-utangnya. Kedua, terdapat keadaan yang membahayakan eksitensi perusahaan yang dapat menyebabkan perusahaan pailit. Jika kreditor menyetujui rencana tersebut, Pengadilan dapat melakukan PKPU selama 24 bulan, dan dapat diperpanjang sampai 12 bulan. Jadi, jangka waktu PKPU di Belgia adalah selama 36 bulan. ${ }^{16}$

Pemberian jangka waktu yang sangat singkat bagi tercapainya kesepakatan perdamaian antara kreditor dalam kerangka PKPU di Indonesia. FV memberikan jangka waktu yang lebih lama kepada debitor untuk mencari penyelesaian, sehingga dapat menjadi celah bagi debitor nakal untuk memenuhi kewajibannya dan setelah boedel pailit sudah minim secara sukarela bersedia dipailitkan. Berbeda dengan UU No. 37/2004 yang justru memberikan inisiatif kepada kreditor untuk bekerjasama dengan debitor menyelesaikan pola penyelesaian utang debitor. ${ }^{17}$

Menurut advokad senior yang pernah menangani permasalahan PKPU adalah agar waktu yang dihabiskan untuk mengurus PKPU tersebut tidak terlalu lama, sehingga Debitor dapat kembali fokus untuk melanjutkan usahanya agar proposal perdamaian yang sudah disahkan (di-homologasi) dapat segera direalisasikan oleh Debitor. ${ }^{18}$ Jelas, pemberian jangka waktu yang diberikan oleh UU

\section{Ibid.}

17 Wawancara dengan Advokad Chandra Nadhi, di Surabaya, tanggal 11 Maret 2017.

18 Wawancara dengan Advokad Jeckson Sitorus, di Jakarta, tanggal 8 Februari 2017. 
No. 37/2004 untuk memberikan jaminan kepada kreditor bahwa utangnya akan dibayar, sementara bagi debitor diberikan waktu yang singkat agar debitor benar-benar mampu untuk melakukan upaya penawaran perdamaian kepada kreditor terkait pembayaran utangutangnya, sehingga debitor dapat melanjutkan usahanya kembali tanpa takut mengalami kepailitan.

Apabila diperbandingkan dengan UU No. 37/2004, jangka waktu PKPU yang diberikan di Indonesia termasuk yang paling singkat. Pemberian jangka waktu yang sangat singkat bagi tercapainya kesepakatan perdamaian antara kreditor dan debitor dalam kerangka PKPU di Indonesia, yang dapat memungkinkan kesepakatan perdamaian yang telah dicapai oleh kreditor dan debitor kurang maksimal.

Seharusnya dalam merumuskan jangka waktu PKPU mempertimbangkan kemampuan perusahaan untuk memenuhi kewajiban debitor yang akan datang. Reorganisasi perusahaan memerlukan waktu yang cukup untuk memberikan kesempatan kepada perusahaan yang masih mempunyai prospek untuk berkembang, melakukan atau melangsungkan kegiatan usahanya, karena aset yang dimiliki oleh debitor lebih besar dibadingkan dengan utangnya. Di samping pertimbangan tersebut di atas, penetapan waktu dalam PKPU seharusnya tetap memperhatikan tujuan UU Kepailitan lainnya. Tujuan itu salah satunya adalah meningkatkan nilai perusahaan yang sedang mengalami kesulitan keuangan, namun masih prospektif untuk berkembang pada yang akan datang. Dengan demikian tujuan melindungi para pihak yang tidak dapat melindungi diri mereka sendiri pun (stakeholder) dapat dilakukan. Pemberian kesempatan mereorganisasi bisnis debitor, berarti akan mengurangi kerugian yang diderita oleh mereka yang bersandar kepada kegiatan usaha suatu perusahaan (stakeholder).

\section{Implikasi Batasan Waktu Penundaan Ke- wajiban Pembayaran Utang Terhadap Rencana Perdamaian Debitor dengan Para Kreditor}

Pada dasarnya tujuan mengajukan permohonan PKPU untuk mengajukan rencana perdamaian. Rencana perdamaian yang memuat tawaran pembayaran sebagian atau seluruh utang kepada kreditor. Adapun tujuan memohon PKPU tersebut, yaitu:

1. Menghindari pailit;

2. Memberikan kesempatan kepada Debitor melanjutkan usahanya, tanpa ada desakan untuk melunasi utang-utangnya; dan

3. Menyehatkan usahanya.

Tahap pertama dalam proses PKPU sepanjang syarat-syarat administrasi sudah dipenuhi, hakim Pengadilan Niaga harus segera mengabulkan serta harus menunjuk hakim pengawas dan mengangkat satu atau lebih pengurus (jika dalam kepailitan disebut kurator). PKPU tersebut dapat diajukan oleh debitor sendiri maupun kreditornya. Ketentuan dapat mengajukan PKPU merupakan ketentuan baru dalam UU No. 37/2004. Jika dalam UU No. 4/1998 dan FV, hanya debitor saja yang dapat mengajukan PKPU. Secara prinsip terdapat dua pola PKPU, yakni: (1) PKPU yang merupakan tangkisan bagi debitor terhadap permohonan kepailitan yang diajukan oleh kreditornya dan (2) PKPU atas inisiatif sendiri debitor yang memperkirakan debitor tidak mampu membayar utang-utangnya.

Pengajuan PKPU kepada Pengadilan Niaga, dengan melengkapi persyaratan:

1. Surat permohonan bermaterai yang ditu- 
jukin kepada ketua Pengadilan Niaga setempat, yang ditandatangani oleh debitor dan penasihat hukumnya;

2. Surat kuasa khususnya asli untuk mengajukan permohonan (penunjukan kuasa pada orangnya bukan pada law firmnya);

3. Izin advokad yang dilegalisir;

4. Alamat dan identitas lengkap kreditor kongkuren disertai jumlah tagihan masing-masing pada debitor;

\section{Financial report;}

6. Dapat dilampirkan rencana perdamain (accoord) yang meliputi tawaran pembayaran seluruh atau sebagian utang kepada para kreditor kongkuren. ${ }^{19}$

Dalam hal permohonan diajukan paling lambat 3 hari sejak tanggal didaftarkannya surat permohonan, hakim harus mengabulkan PKPU sementara dan harus menunjuk seorang hakim pengawas dari hakim Pengadilan Niaga serta mengangkat 1 atau lebih pengurus yang bersama dengan debitor mengurus harta debitor. Sedangkan hal permohonan kepailitan diajukan oleh kreditor, Pengadilan Niaga dalam waktu paling lambat 20 hari sejak tanggal didaftarkannya surat permohonan, harus mengabulkan permohonan PKPU sementara dan harus menunjuk hakim pengawas dari hakim Pengadilan Niaga serta mengangkat 1 atau lebih pengurus yang bersama dengan debitor mengurus harta debitor. ${ }^{20}$

Jangka waktu PKPU adalah paling lama 45 hari. Segera setelah putusan PKPU sementara diucapkan, Pengadilan Niaga melalui pengurus wajib memanggil debitor dan kreditor yang dikenal dengan surat tercatat atau

19 M. Hadi Subhan. 2009. Hukum Kepailitan: Prinsip, Norma dan Praktik Peradilan. Jakarta: Kencana Prenada Media Group, hlm. 148.

20

Ibid, hlm. 148 melalui kurir, untuk menghadap dalam sidang yang diselenggarakan paling lama pada hari ke 45 terhitung sejak putusan PKPU sementara diucapkan. ${ }^{21}$

Pengurus harus segera mengumumkan putusan PKPU sementara dalam Berita Negara dan dalam 2 surat kabar harian yang ditunjuk oleh hakim pengawas. Dalam pengumuman sekaligus juga memuat undangan untuk hadir pada persidangan yang merupakan rapat permusyawaratan hakim tersebut. Jika ada rencana perdamaian juga harus disebutkan mengenai hal ini dalam pengumuman tersebut. Pengumuman ini harus dilakukan oleh pengurus paling lambat 21 hari sebelum tanggal sidang yang direncanakan.

Akibat hukum putusan PKPU sementara bagi para kreditor adalah bahwa kreditor tersebut tidak dapat menagih utang-utangnya selama PKPU sementara tersebut, karena debitor tidak diwajibkan untuk membayar utang-utangnya. Sedangkan akibat hukum bagi debitor adalah dengan adanya PKPU tersebut, maka seluruh kekayaan debitor berada di bawah pengawasan pengurus, sehingga debitor tidak lagi berwenang terhadap harta kekayaannya untuk melakukan tindakan pengurusan maupun tindakan pengalihan tanpa persetujuan pengurus. Tindakan debitor terhadap kekayaan tanpa persetujuan pengurus pada dasarnya tidak mengikat kekayaannya.

Pada hari yang telah ditentukan, majelis hakim menggelar persidangan permohonan PKPU tetap. Dalam sidang tersebut akan diputuskan apakah dapat diberikan PKPU secara tetap ataukah sebaliknya akan ditolak. PKPU tetap akan ditetapkan secara tetap apabila disetujui oleh lebih dari 1/2 jumlah kreditor kongkuren yang hadir dalam sidang

$21 \quad$ Ibid, hlm. 149 
dan mewakili paling sedikit $2 / 3$ bagian dari seluruh tagihan kreditor kongkuren yang hadir dalam sidang tersebut. Hal ini berarti bahwa kreditor kongkuren yang tidak hadir dalam sidang tidak mempengaruhi kourum. Persetujuan oleh para kreditor separatis juga diperlukan dalam PKPU. Sementara itu, ketentuan persetujuan kreditor separatis adalah lebih dari 1/2 jumlah kreditor yang piutangnya dijamin dengan gadai, jaminan fidusia, hak tanggungan, hipotek atau hak agunan atas kebendaan lainya yang hadir dan mewakili paling sedikit 2/3 bagian dari keseluruhan tagihan kreditor atau kuasanya yang ada dalam sidang tersebut. ${ }^{22}$

Terhadap putusan PKPU tidak dapat diajukan upaya hukum apapun. Jika PKPU tetap disetujui oleh majelis, maka jangka waktu PKPU tetap adalah maksimal 270 hari. Proses PKPU berlangsung selama 270 hari sudah termasuk 45 hari untuk jangka waktu PKPU sementara. Jangka waktu tersebut merupakan jangka waktu yang mutlak dan sudah tidak dapat diperpanjang lagi. Apabila jangka waktu berakhir dan perdamaian belum memperoleh kekuatan yang pasti, meskipun rencana perdamaian telah memenuhi kourum, dengan sendirinya PKPU berakhir secara hukum dan debitor dinyatakan pailit.

Dalam hal pembatasan waktu yang diberlakukan oleh UU No. 37/2004 bukan penyebab gagalnya upaya perdamaian yang dilakukan oleh debitor dengan para kreditor. Tetapi sebenarnya inti dari penyebab gagalnya perdamaian adalah tidak bulatnya niat kreditor dan debitor untuk mewujudkan perdamaian dalam PKPU. ${ }^{23}$

22 Ibid, 150

23 Wawancara dengan Adokad Jeckson Sitorus di Jakarta, tanggal 8 Februari 2017.
Tidak bulatnya niat dari debitor dan kreditor untuk melakukan perdamaian, seperti contoh, debitor telah setuju untuk diadakannya perdamaian dan telah memberikan proposal perdamaian kepada kreditor sesuai dengan kemampuan debitor, namun para kreditor, dikarenakan ada itikad tidak baik terhadap debitor atau bisa juga dikarenakan ada unsur persaingan usaha yang tidak sehat (kreditor berharap usaha debitor berhenti atau ditutup), maka para kreditor itu sengaja menolak terus proposal perdamaian yang diajukan oleh debitor. $^{24}$

Menurut advokad sekaligus pengurus yang pernah menangani permohonan PKPU mengatakan bahwa waktu yang diberikan dalam melakukan upaya perdamaian terhadap proses PKPU tersebut kurang cukup, mengingat debitor yang mengajukan PKPU biasanya sudah setengah mati melakukan upaya perdamaian, sementara dengan waktu yang diberikan sangat sempit maka perdamaian juga akan sulit untuk tercapai. ${ }^{25}$

Batas waktu 270 hari bukan merupakan waktu untuk utang debitor selesai dilunasi, namun adalah jangka waktu yang diberikan dalam proses penyelesaian utang tersebut. Apabila dalam waktu tersebut pihak debitor telah sepakat untuk melakukan restrukturisasi utang dengan pola penyelesaian yang berupa potongan (hair cut) untuk sebagian bunga pinjaman dan penundaan pembayaran (grace period) selama 6 bulan, baru setelah itu sisanya akan dicicil dengan fix rate interest selama 2 tahun. Apabila proposal perdamaian telah disepakati, maka dalam waktu sebelum mencapai 270 hari sudah dapat di-

\footnotetext{
24 Ibid.

25 Wawancara dengan Advokad Chandra di Surabaya, tanggal 11 Maret 2017.
} 
lakukan rapat untuk menentukan persetujuan PKPU tersebut, namun apabila dalam waktu setelah 270 hari tersebut pihak debitor tidak melaksanakannya, maka dapat dilaksanakan penetapan pailit. ${ }^{26}$

Pentingnya mewujudkan atau menyepakati suatu perjanjian perdamaian yang merupakan inti dari terlaksananya PKPU, sebab bagaimanapun kondisi perusahaan debitor sudah berada pada posisi yang lemah, sehingga sebagian utang-utang perusahaan mungkin sudah jatuh tempo dan belum dapat dibayar. debitor berusaha untuk tidak pailit sebab melihat prospek dan peluang usaha untuk bangkit masih ada, mungkin pertimbangan itu berdasarkan pada evaluasi produksi asset perusahaan dan utang piutangnya yang sedang berjalan. Namun bagaimanapun masih kondusifnya perusahaan tersebut,utang tetap utang yang telah jatuh tempo tetap dapat ditagih oleh pihak.

Kreditor bahkan mungkin perusahaan tersebut dimohonkan pailit dengan adanya utang kepada lebih dari satu orang kreditor yang telah ada yang sudah jatuh tempo. Oleh karenanya dalam setiap pengajuan PKPU, masalah rencana perdamaian ini merupakan kunci pokok bagaimana debitor dapat membuat atau mengusulkan suatu rencana perdamaian(composition plan) yang menarik pihak kreditor untuk bersama-sama berunding dan memutus yang terbaik bagi kedua belah pihak.

Fungsi perdamaian dalam PKPU berbeda dengan fungsi perdamaian dalam kepailitan. Dalam bidang PKPU fungsi perdamaian lebih luas. Jika dalam kepailitan fungsi perdamaian

26 Edward Manik. 2012. Cara Mudah Memahami Proses Kepailitan dan Penundaan Kewajiban Pembayaran Utang. Bandung: Mandar Maju, hlm. 141. hanya sebatas untuk bagaimana cara pemeberesan dan pembagian harta pailit, tetapi dalam PKPU, termasuk persetujuan terhadap dilakukannya restrukturisasi utang-utang debitor.

Perlu diingat bahwa jika dalam PKPU telah dilakukan perdamaian, maka setelah pailit nantinya tidak boleh lagi ditawarkan suatu perdamaian sebagaimana ditetapkan dalam Pasal 292 UU No. 37/2004. Ketentuan ini mengindikasikan bahwa perdamaian dalam PKPU dengan perdamaian dalam kepailitan sebenarnya juga tidak begitu jauh berbeda, sehingga tidak perlu dilakukan dua kali hal yang hampir sama tersebut.

Haruslah dicermati bahwa PKPU berbeda dengan pengertian jangka waktu rescheduling utang sebagaimana istilah yang dikenal dalam industri perbankan. Jangka waktu 270 hari itu adalah jangka waktu bagi debitor dan para kreditor untuk membuat kesepakatan perdamaian. Waktu 270 hari tersebut dihitung sejak PKPU sementara diputuskan oleh Pengadilan Niaga. Jadi,dalam batas waktu 270 hari tersebut sudah termasuk 45 hari PKPU sementara. $^{27}$

Sesuai dengan Pasal 228 ayat (5) UU No. 37/2004, PKPU memang mempunyai batas maksimum waktu 270 hari dengan konsekuensi hukum dalam masa 270 hari tersebut upaya perdamaian harus segera disepakati. Batas maksimum artinya dapat saja ditentukan suatu batas waktu untuk PKPU yang kurang dari 270 hari tersebut. Jika ada perpanjangan jangka waktu terhadap PKPU, maka perpanjangan tersebut juga harus dalam waktu 270 hari itu.

Berkaitan dengan jangka waktu batas maksimum 270 hari yang dimiliki oleh de-

27 Wawancara dengan Advokad Jeckson Sitorus, di Jakarta, tanggal 8 Februari 2017. 
bitor dalam melakukan upaya perdamaian dalam PKPU bukan merupakan penyebab gagalnya pedamaian tersebut, tetapi seperti yang sudah disebutkan bahwa jangka waktu tersebut bukan mengharuskan debitor untuk melakukan pelunasan utang-utangnya kepada kreditor, namun jangka waktu tersebut ditujukan untuk membatasi debitor dalam membuat atau mengusulkan suatu rencana perdamaian (composition plan) yang menarik pihak kreditor untuk bersama-sama berunding dan memutus yang terbaik bagi kedua belah pihak.

Perdamaian yang merupakan penentu dari terlaksananya PKPU dalam tahap ini sebenarnya kondisi perusahaan debitor sudah berada pada posisi yang lemah, sehingga sebagian utang-utang perusahaan mungkin sudah jatuh tempo dan belum dapat dibayar. Debitor berusaha untuk tidak pailit sebab melihat prospek dan peluang usaha untuk bangkit masih ada, namun dalam beberapa kasus ada saja kreditor yang sengaja atau memiliki itikad tidak baik dengan tidak bulatnya niat dari debitor dan kreditor untuk melakukan perdamaian. Misalnya debitor telah setuju untuk diadakannya perdamaian dan telah memberikan proposal perdamaian kepada kreditor sesuai dengan kemampuan debitor, namun para kreditor dikarenakan ada itikad tidak baik terhadap debitor atau bisa juga dikarenakan ada unsur persaingan usaha yang tidak sehat (kreditor berharap usaha debitor berhenti atau ditutup), maka para kreditor itu sengaja menolak terus proposal perdamaian yang diajukan oleh debitor. Ddalam keadaan seperti ini jelas posisi debitor tidak diuntungkan, karena pengajuan proposal yang sebelah pihak yang hanya dilakukan oleh debitor kepada para kreditor, seharusnya proposal perdamaian juga diajukan oleh para kreditor kepada debitor kemudian dibuat kesepakatan bersama, sehingga tercapai perdamaian sesuai dengan tujuan dari upaya PKPU. Hal lain yang membuat gagalnya upaya perdamaian adalah tingginya syarat voting dari para kreditor yang menyetujui PKPU kepada debitor

Terlihat bahwa posisi tawar yang dimiliki oleh debitor sebenarnya sangat lemah artinya meskipun debitor berupaya melakukan upaya perdamaian dengan para kreditornya, namun semua tergantung pada voting persetujuan dan itikad baik dari para kreditor. Meskipun jangka waktu bukan penentu gagalnya suatu upaya perdamaian dalam PKPU, namun dengan jangka waktu yang singkat yang diberikan UU No. 37/2004, tetap memberikan pengaruh terhadap proses tercapainya PKPU, paling tidak jika jangka waktu yang diberikan lebih dari 270 hari dapat memberi kesempatan sedikit lebih lama bagi debitor untuk melakukan negosiasi dengan para kreditornya untuk mencapai kesepakatan bersama terkait pembayaran utang-utang debitor kepada para kreditornya.

Pemberian jangka waktu yang singkat dapat membuat debitor sulit untuk melakukan upaya PKPU, artinya debitor tidak memiliki waktu yang cukup dalam melakukan negosiasi dengan para kreditor terkait proses pembayaran utang, sehingga jangka waktu yang diberikan oleh UU No. 37/2004 terhadap PKPU belum optimal bagi debitor. Berarti dapat dikatakan bahwa jangka waktu bukan penyebab gagalnya upaya perdamaian, tetapi jangka waktu dapat memberikan pengaruh bagi tercapainya upaya perdamaian sesuai dengan tujuan yang diharapkan oleh UU No. $37 / 2004$.

\section{Perlindungan Hukum Bagi Kepentin- gan Debitor Untuk Mencegah Kepailitan Terkait dengan Batasan Jangka Wak- tu Penundaan Kewajiban Pembayaran}




\section{Utang.}

Konsep perlindungan hukum diartikan sebagai kumpulan peraturan atau kaidah yang dapat melindungi suatu hal dari hal lainnya. Berkaitan dengan debitor dengan kreditorkreditor, berarti hukum memberikan perlindungan terhadap hak-hak debitor dari sesuatu yang mengakibatkan tidak terpenuhi hak-hak tersebut. ${ }^{28}$

Hukum pada dasarnya berfungsi untuk memberikan perlindungan kepada setiap kepentingan manusia. Hal itu disebabkan dalam kehidupan dan hubungan hukum, para pihak yang terkait mempunyai kepentingannya masing-masing. Kepentingan dimaksud adakalanya bersamaan, berbeda atau bahkan bertentangan. Dalam hal kepentingan tersebut bersamaan barangkali tidak akan menimbulkan masalah dalam kehidupan atau hubungan hukum tersebut. Demikian pula dalam hal kepentingannya berbeda, tetapi tidak dipertentangkan atau tidak dipersoalkan. Menjadi masalah dalam hal kepentingan tersebut bertentangan dan dimunculkan kepermukaan sehinga menimbulkan suatu konflik kepentin$\operatorname{gan}^{29}$

Kepentingan manusia merupakan sesuatu yang harus dilindungi oleh hukum, karena memang hukum itu dibuat oleh dan untuk manusia atau masyarakat. Berangkat dari pemahaman ini, kata perlindungan hukum sebenarnya erat kaitannya dengan fungsi hukum dan tujuan hukum, mengenai apa fungsi hukum pada umumnya ahli hukum sudah sepakat

28 http://www.pps.unud.ac.id/thesis/pdf thesis/unud-1558-765926439-tesis wayanwesnaastara_1290561047. pdf., diunduh tanggal 18 Februari 2017.

29 Man S Sastrawidjaja. 2006. Hukum Kepailitan dan Penundaan Kewajiban Pembayaran Utang. Bandung: Alumni, hlm. 71. mengatakan bahwa fungsi hukum merupakan perlindungan kepentingan manusia. ${ }^{30}$

Sesuai dengan Pasal 28D ayat (1) UUD 1945 disebutkan bahwa "setiap orang berhak atas pengakuan, jaminan, perlindungan dan kepastian hukum yang adil serta perlakuan yang sama dihadapan hukum”. Ketentuan tersebut memberikan makna, bahwa UndangUndang menghendaki perlindungan hukum dan kepastian hukum yang mengandung keadilan dalam suatu peraturan.

UU No. 37/2004 memiliki tujuan agar debitor yang merupakan perusahaan mempunyai waktu yang cukup untuk berusaha mengadakan perdamaian dengan para kreditor dalam menyelesaikan utang-utangnya. PKPU memberikan kesempatan kepada debitor untuk melakukan reorganisasi usaha atau manajemen perusahaan atau melakukan restrukturisasi utang-utangnya dalam tenggang waktu PKPU, yang pada akhirnya debitor akan dapat meneruskan kegiatan usahanya. Pada PKPU, debitor tidak kehilangan haknya untuk mengurus perusahaan dan asetnya, sehingga debitor tetap mempunyai wewenang untuk melakukan pengurusan perusahaannya. ${ }^{31}$

Tujuan dari PKPU tersebut menunjukan bahwa debitor diberikan kesempatan oleh UU No. 37/2004 untuk berusaha melakukan perdamaian dengan para kreditor mengenai utang-utangnya, sehingga debitor terhindar dari kepailitan dan dapat melanjutkan usahanya kembali dan jaminan bagi para kreditor agar hak-hak mereka terkait piutang dipenuhi oleh kreditor. Rencana perdamaian mutlak

30 Bernad Nainggolan. 2011. Perlindungan Hukum Seimbang, Debitor, Kreditor dan Pihak-Pihak Berkepentingan dalam Kepailitan. Bandung: Alumni, hlm. 22.

31 Siti Anisah. Op.Cit, hlm. 280. 
merupakan hak yang dimiliki oleh debitor yang berada dalam PKPU, apabila debitor tidak mengajukan rencana perdamaian tersebut sampai PKPU berakhir, maka debitor akan dinyatakan pailit oleh Pengadilan Niaga. Perlu diketahui bahwa tidak ada satupun aturan yang mewajibkan materi dan bentuk pengajuan rencana perdamaian debitor kepada para kreditornya, rencana perdamaian tersebut disesuaikan dengan situasi, kondisi dan kepentingan antara debitor dengan para kreditornya yang bersangkutan. ${ }^{32}$

Terkait permohonan PKPU yang dikabulkan oleh Pengadilan Niaga, membuat debitor dalam keadaan PKPU sementara untuk jangka waktu 45 hari. Apabila debitor yang bersangkutan merasa perlu untuk memperpanjang proses PKPU tersebut, maka atas permintaan debitor PKPU, dapat diajukan permohonan PKPU tetap, yang harus disetujui oleh para kreditor berdasarkan kourum yang diatur dalam UU No. 37/2004. Apabila kourum tersebut tidak terpenuhi, maka Pengadilan Niaga harus menyatakan debitor tersebut dalam keadaan pailit. Ketentuan mengenai hal ini terdapat di dalam Pasal 230 ayat (1) UU No. 37/2004.

Bila ditelisik UU No. 37/2004 sudah cukup menjamin perlindungan hukum bagi debitor untuk mencegah kepailitan, sebagaimana diatur dalam Pasal 222 ayat (2), yang kemudian diperkuat kembali yaitu melalui Pasal 225 ayat (2) UU No. 37/2004. Bunyinya Pasal 222 ayat (2) tersebut, menyatakan: "Debitor yang tidak dapat atau memperkirakan tidak akan dapat melanjutkan membayar utangutangnya yang sudah jatuh waktu dan dapat ditagih, dapat memohon penundaan kewa-

32 Wawancara dengan Advokad Jeckson Sitorus, di Jakarta, 8 Februari 2017. jiban pembayaran utang, dengan maksud untuk mengajukan rencana perdamaian yang meliputi tawaran pembayaran sebagian atau seluruh utang kepada kreditor." Kemudian dalam Pasal Pasal 225 ayat (2) ditegaskan, bahwa "Dalam hal permohonan diajukan oleh debitor, Pengadilan dalam waktu paling lambat 3 (tiga) hari sejak tanggal didaftarkannya surat permohonan sebagaimana dimaksud dalam Pasal 224 ayat (1) harus mengabulkan penundaan kewajiban pembayaran utang sementara dan harus menunjuk seorang Hakim Pengawas dari hakim pengadilan serta mengangkat 1 (satu) atau lebih pengurus yang bersama dengan debitor mengurus harta debitor."

Berdasarkan kedua ketentuan tersebut di atas, pihak termohon pailit diberikan kesempatan untuk mengajukan perlawanan atas permohonan pailit yang diajukan kepada dirinya. Apalagi dengan adanya ketentuan Pasal 225 ayat (2) UU No. 37/2004 tersebut di atas, yang menyatakan bahwa dalam waktu paling lambat 3 (tiga) hari sejak tanggal didaftarkan, artinya apabila debitor sudah mengajukan permohonan PKPU atas permohonan pailit yang diajukan terhadap dirinya, maka yang harus terlebih dahulu diputus adalah permohonan PKPU yang diajukan oleh debitor daripada permohon pailit yang diajukan oleh kreditor. Dalam praktik beracara di Pengadilan Niaga, terhadap permohonan pailit dapat ditangkis atau dilawan dengan PKPU. Artinya dalam hal orang perorangan atau badan hukum hendak dipailitkan, debitor dapat mengajukan eksepsi terhadap permohonan pailit tersebut dengan mengajukan permohonan PKPU ke Pengadilan Niaga. ${ }^{33}$ Sesungguhnya PKPU merupakan bentuk perlindungan terha-

33 Wawancara dengan Advokad Jeckson Sitorus, di Jakarta, tangga; 8 Februari 2017. 
dap debitor yang masih beritikad baik untuk membayar hutang-hutangnya kepada seluruh kreditornya.

Maksud dari pemberian PKPU kepada debitor adalah agar debitor yang berada dalam keadaan insolven (insolvency) tersebut mempunyai kesempatan untuk mengajukan suatu rencana perdamaian, baik berupa tawaran untuk pembayaran utang secara keseluruhan ataupun sebagian atas utangnya. Oleh karena itu, PKPU merupakan kesempatan bagi debitor untuk melunasi atau melaksanakan kewajibannya atas utang-utang tersebut, sehingga debitor tersebut tidak sampai dinyatakan pailit. Mekanisme PKPU belum memberikan kesempatan yang luas bagi debitor untuk memperbaiki kinerja perusahaan. Dalam hal ini dapat dilihat dalam pemberian waktu yang relatif singkat bagi debitor untuk melakukan perbaikan bagi perusahaannya. Dominasi kreditor dalam menentukan perdamaian, dan adanya keterbatasan kesewenangan yang dimiliki oleh debitor untuk terus mengelola perusahaan yang harus dilakukannya bersama sama dengan pengurus. Selain itu juga UU No. 37/2004 belum memisahkan kepailitan terhadap perusahaan dan perorangan, pada hal tujuan dan manfaat keduanya berbeda. ${ }^{34}$

Searah dengan upaya perlindungan hukum bagi debitor tehadap tuntutan kepailitan, dalam Pasal 229 ayat (3) dan (4) UU No. 37/2004 diatur tentang kedudukan yang lebih dipentingkan tehadap permohonan PKPU. Pada pelaksanaannya PKPU selalu berakhir dengan kepailitan, artinya tujuan yang diberikan oleh UU No. 37/2004 untuk mencegah kepailitan bagi debitor sia-sia. Dari segi tujuan PKPU sudah memberikan perlindungan

34 Wawancara dengan Advokad Chandra Nadhi, di Surabaya, tanggal 11 Maret 2017. hukum bagi debitor, tetapi pemberian jangka waktu yang ditentukan oleh UU No. 37/2004 dalam proses PKPU dirasa belum optimal, karena terlalu singkat, sehingga upaya PKPU yang dilakukan oleh debitor agar terhindar dari kepailitan justru malah menjadi alat bagi para kreditor untuk memailitkan debitornya.

Undang-undang Kepailitan yang baik haruslah dilandaskan pada asas untuk memberikan perlindungan yang seimbang bagi semua pihak yang terkait dan berkepentingan terhadap kepailitan seorang atau perusahaan. Dalam hal ini, Undang-undang Kepailitan yang baik seyogyanya tidak hanya memberikan perlindungan bagi kreditor saja. Kepentingan debitor dan stakeholder-nya juga harus sangat diperhatikan. Tidak terpenuhinya tujuan PKPU akan menyebabkan lembaga PKPU tersebut tidak akan berfungsi sebagaimana tujuan pendirian atau pembentukannya.

Secara tersirat UU No. 37/2004 telah memberikan jaminan perlindungan hukum bagi debitor dalam melakukan upaya PKPU, berupa kepastian terhadap kreditor akan piutangnya dibayar oleh debitor dan juga telah membantu debitor untuk mecegah kepailitan. Namun dengan adanya batasan jangka waktu yang relatif singkat bagi debitor untuk melakukan upaya perdamaian dalam PKPU dengan para kreditor, hal ini dirasa belum optimal mengingat dengan jangka waktu yang singkat tersebut sangat sulit bagi debitor untuk dapat mecapai kesepakatan melalui upaya perdamaian dengan para kreditor, sehingga tujuan yg diberikan oleh PKPU tersebut akan sulit tercapai.

\section{PENUTUP}

1. Pemberian jangka waktu dalam PKPU oleh UU No. 37/2004 memiliki tujuan untuk memberikan jaminan kepada kreditor 
bahwa utangnya akan dibayar, sementara bagi debitor diberikan jangka waktu yang singkat agar debitor benar-benar mampu untuk melakukan upaya penawaran perdamaian kepada kreditor terkait dengan pembayaran utang-untangnya, sehingga debitor dapat melanjutkan usahanya kembali tanpa takut mengalami kepailitan. Apabila diperbandingkan ketentuan mengenai jangka waktu PKPU dalam UU No. 37/2004 dengan ketentuan yang berlaku di Belanda, Jerman dan Belgia, serta ketentuan FV, jangka waktu PKPU yang diberikan di Indonesia termasuk yang paling singkat. Pemberian jangka waktu yang sangat singkat bagi tercapainya kesepakatan perdamaian antara kreditor dan debitor dalam kerangka PKPU, yang dapat memungkinkan kesepakatan perdamaian yang telah dicapai oleh kreditor dan debitor kurang maksimal.

2. Posisi tawar yang dimiliki oleh debitor dalam PKPU sebenarnya sangat lemah, meskipun debitor berupaya melakukan upaya perdamaian dengan para kreditornya, namun hal itu tergantung pada voting persetujuan dan itikad baik dari para kreditor. Pembatasan jangka waktu PKPU bukan penentu gagalnya suatu upaya perdamaian dalam PKPU. Akan tetapi dengan jangka waktu yang singkat yang diberikan UU No. 37/2004 tetap memberikan pengaruh terhadap proses tercapainya PKPU.

3. Pembatasan jangka waktu PKPU dalam UU No. 37/2004 telah memberikan jaminan perlindungan berupa kepastian hukum terhadap kreditor akan piutangnya dibayar oleh debitor dan juga telah membantu debitor untuk mecegah kepailitan, seperti memberikan kesem- patan kepada debitor untuk melakukan reorganisasi usaha, manajemen perusahaan, atau melakukan restrukturisasi utang-utangnya dalam tenggang jangka waktu PKPU, kemudian debitor tidak kehilangan haknya untuk mengurus perusahaan dan asetnya, sehingga debitor tetap mempunyai wewenang untuk melakukan pengurusan perusahaannya. Adanya ketentuan batasan jangka waktu yang relatif singkat bagi debitor untuk melakukan upaya perdamaian dengan para kreditor tersebut sangat sulit bagi debitor untuk dapat mecapai kesepakatan melalui upaya perdamaian dengan para kreditor, sehingga tujuan yang diberikan oleh PKPU akan sulit tercapai.

\section{BIBLIOGRAFI}

Anisah, Siti. 2008. Perlindungan Kepentingan Kreditor dan Debitor Dalam Hukum Kepailitan Di Indonesia. Yogyakarta: Total Media.

Bagir, Haidar. 1995. Era Baru Manajemen Etis. Jakarta: Mizan.

Dewata, Mukti Fajar Nur dan Yulianto Achmad. 2010. Dualisme Penelitian Normatif dan Empiris. Yogyakarta: Pustaka Pelajar.

Fuady, Munir. 2010. Hukum Kepailitan dalam Teori dan Praktik. Bandung: Citra Aditya Bakti.

Fuady, Munir. 2001. Pengantar Hukum Bisnis. Bandung: Citra Aditya.

Hadjon, Philipus M. 1987. Perlindungan Hukum bagi Rakyat Indonesia, sebuah studi Tentang Prinsip-Prinsipnya, Penanganannya oleh Pengadilan dalam Lingkungan Peradilan Umum. Surabaya: Bina Ilmu.

http://www.pps.unud.ac.id/thesis/pdf_thesis/ 
unud.

http://nasional.kontan.co.id.

http://www.hukumonline.com

Jono. 2010. Hukum Kepailitan. Jakarta: Sinar Grafika.

Manik, Edward. 2012. Cara Mudah Memahami Proses Kepailitan dan Penundaan Kewajiban Pembayaran Utang. Bandung: Mandar Maju.

Mertokusumo, Sudikno. 2002. Hukum Acara Perdata Indonesia. Yogyakarta: Liberty.

Mertokusumo, Sudikno. 2010. Mengenal Hukum Suatu Pengantar. Yogyakarta: Liberty.

Nainggolan, Bernad. 2011. Perlindungan Hukum Seimbang, Debitor, Kreditor dan Pihak-Pihak Berkepentingan dalam Kepailitan. Bandung: Alumni.

Nating, Imran. 2004. Peranan dan Tanggung Jawab Kurator Dalam Pengurusan dan Pemberesan Harta Pailit. Jakarta: Raja Grapindo Persada.

Novita, Sari. 2015. Perlindungan Hukum Terhadap Independensi Kurator Dalam Melaksanakan Kewenangannya Mengurus dan Membereskan Harta Pailit Beradasarkan UU No. 37 Tahun 2004 Tentang Kepailitan dan Penundaan Kewajiban Pembayaran Utang. Yogyakarta: Fakultas Hukum UGM.

Purba, Jamslin. 2013. Perlindungan Hukum Terhadap Kreditor Kecil Melalui Penundaan Kewajiban Pembayaran Utang Berdasarkan Undang-Undang No. 37 Tahun 2004 tentang Kepailitan dan Penundaan Kewajiban Pembayaran Utang (PKPU) Sebagai Sarana Restrukturisasi Utang Debitor. Yogyakarta: Fakultas Hukum UGM.
Sastrawidjaja, Man S. 2006. Hukum Kepailitan dan Penundaan Kewajiban Pembayaran Utang. Bandung: Alumni.

Simatupang, Richard Burton. 2007. Aspek Hukum Dalam Bisnis. Jakarta: Rineka Cipta.

Sinaga, Syamsudin M. 2012. Hukum Kepailitan Indonesia. Jakarta: Tatanusa.

Soekanto, Soerjono. 2005. Pengantar Penelitian Hukum. Jakarta: UI Press.

Subhan, M. Hadi. 2009. Hukum Kepailitan: Prinsip, Norma dan Praktik Peradilan. Jakarta: Kencana Prenada Media Group.

Sudiarawan, Kadek Agus. 2014. Kajian Terhadap Prinsip Tupe Sebagai Upaya Perlindungan Hukum Terhadap Perkrja Dalam Pelaksanaan Outsourcing Berdasarkan PKWT. Yogyakarta: Magister Hukum Bisnis UGM.

Sulaiman, Robinton dan Joko Prabowo. 2000. Lebih Jauh Tentang Kepailitan (Tinjauan Yuridis Tanggung Jawab Komisaris, Direksi dan Pemegang Saham Terhadap Perusahaan Pailit). Karawaci: Fakultas Hukum Universitas Pelita Harapan.

Sunarmi. 2010. Hukum Kepailitan Edisi 2. Jakarta: Sofimedia.

Supramono, Gatot. 2013. Perjanjian UtangPiutang. Jakarta: Kencana Prenada Media Group.

Suyatno. R. Anto. 2012. Pemanfaatan Penundaan Kewajiban Pembayaran Utang Sebagai Upaya Mencegah Kepailitan. Jakarta: Kencana Prenada Media Group.

Syahdeini, Sutan Remy. 2008. Hukum Kepailitan Memahami Undang-undang No .37 Tahun 2004 tentang Kepailitan. Jakarta: Grafiti. 


\section{Peraturan Perundang-Undangan}

Kitab Undang-undang Hukum Perdata, terjemahan Burgerlijk Wetboek (Staatsblad Tahun 1847 Nomor 23) dengan tambahan Undang-Undang Pokok Agraria dan Undang-Undang Perkawinan. Diterjemahkan oleh R. Subekti dan R. Tjitrosudibio. 1985. Jakarta: Pradya Paramita.

Kitab Undang-Undang Hukum Dagang dan Undang-Undang Kepailitan, terjemahan Wetboek van Koophandel en Faillissements Verordening. Diterjemahkan oleh R. Subekti dan R. Tjitrosudibio. 1982. Jakarta: Pradnya Paramita.

Undang-Undang Dasar Negara Negara Republik Indonesia Tahun 1945.

Undang-Undang Nomor 4 Tahun 1998 tentang Penetapan Peraturan Pemerintah Pengganti Undang-Undang Nomor 1 Tahun 1998 tentang Perubahan Atas Undang-Undang tentang Kepailitan Menjadi Undang-Undang (Lembaran Negara Republik Indonesia Tahun 1998 Nomor 135, Tambahan Lembaran Negara Republik Indonesia Nomor 3778).

Undang-Undang Nomor 37 Tahun 2004 tentang Kepailitan dan Penundaan Kewajiban Pembayaran Utang (Lembaran Negara Republik Indonesia Tahun 2004 Nomor 131, Tambahan Lembaran Negara Republik Indonesia Nomor 4433). 